TITLE:

\title{
Short Tribute to Prof. Toshisada Nishida
}

$\operatorname{AUTHOR}(S)$ :

McGrew, William C.

\section{CITATION:}

McGrew, William C.. Short Tribute to Prof. Toshisada Nishida. Pan Africa News 2011, 18(special issue): 4-4

ISSUE DATE:

2011-09

URL:

http://hdl.handle.net/2433/147292

RIGHT:

Copyright (C) Pan Africa News. 
ried the lady, Miss Haruko Kitayama. So for marriage, he again left me behind.

I vaguely believed that I would precede him in only one thing: entering the next world, for I have indulged in over-eating and over-drinking wherever I stayed, in Japan, Africa or the Amazon, without learning anything. That contrasted greatly with Nishida-san, but he preceded me even in this.

For me, he was an invaluable and truly great friend.

May his soul rest in peace.

(English translation by Noriko Itoh)

\section{Short Tribute to Prof. Toshisada Nishida}

\author{
William C. McGrew \\ Cambridge University, UK
}

Many will write of his scientific and academic achievements, which were great and many. Others will write of his commitment to Mahale, its chimpanzees, and its conservation. Here I wish to recall the pleasure of his company and his friendship, in a couple of personal memories:

Only three primatologists attended both WennerGren meetings on The Great Apes (1974, Burg Wartenstein, Austria; 1994, Cabo San Lucas, Mexico): Prof. Jane Goodall, Prof. Nishida, and myself. At the first one, he and I were almost the youngest persons there; at the second one, we were almost the oldest. We both occasionally enjoyed a celebratory alcoholic beverage. Laurie Obbink reminds me that after dinner on the first night at Cabo, Prof. Nishida bowed politely and asked her, "Please, where can we drink more?" She obliged, and we raised our glasses, more than once.

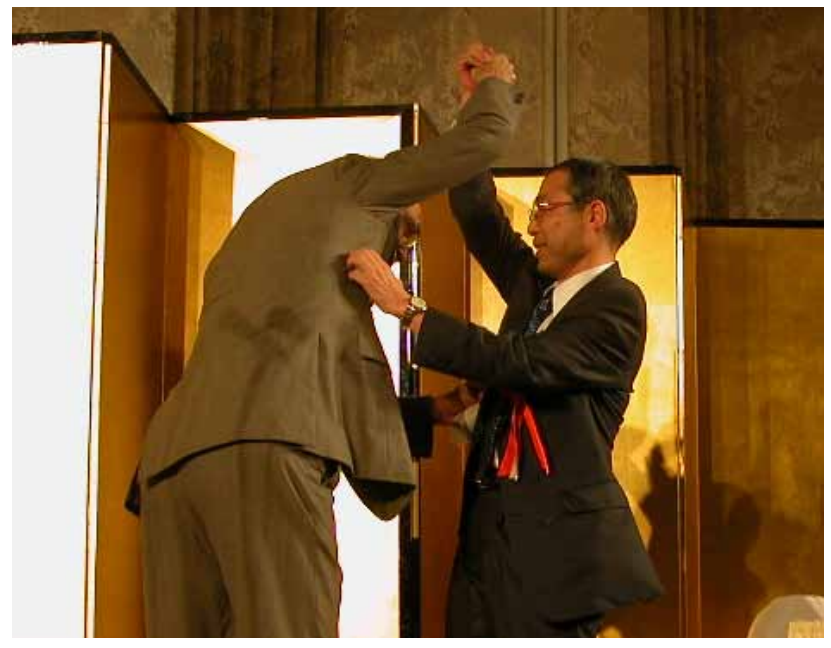

One time during one of the Understanding Chimpanzees conferences in Chicago, I took him to Wrigley Field to see the Cubs play. He admitted to not being a real baseball fan, though he recalled that his father had taken him to games. He paid attention during the play, and was appreciative of the atmosphere of that grand old stadium, but seemed a bit restless. It turned out that what he really wanted to do was stock up on souvenirs, such as baseball hats, pennants, etc., especially to do with Sammy Sosa (a famous Cub homerun hitter of that era). He did so, and we came away, with arms full.

Such are the small memories that never fade.

\section{Recollection of Nishida-san: His Days at the University of Tokyo}

\author{
Ryutaro Ohtsuka \\ Japan Wildlife Research Center, Japan
}

I remember that it was late autumn of 1969 that I met Nishida-san for the first time. He came to see the room of the ecological anthropology group. He had been recently been hired as a research associate in the Department of Anthropology at the University of Tokyo. Nishida-san arrived to take up the position in December of the year, and was promoted to Lecturer and Associate Professor afterwards. He worked in the same department until March, 1988. Thus, he taught at the University of Tokyo for over 18 years, or longer than the period he taught at Kyoto University.

Nishida-san joined the room occupied by the ecological anthropology group, which included the late Dr. Reizo Harako (doctor's course), Dr. Jun Takeda, and me (master's course). Only a few other research students and undergraduate students occasionally spent time in the room, since the ecological anthropology group had just started. We conducted a survey of the fishing communities and matagi hunters, but nobody had investigated the primates. It was only for four months that I was with Nishida-san in the Department of Anthropology, because the following April I became a research associate in the Department of Human Ecology at the University of Tokyo. However, the buildings were near to each other and we met frequently even after that.

Harako-san was a master of the room in the ecological anthropology group. He had been a surgeon but was attracted to the Pygmy people in Africa and was determined to learn anthropology. He was already over 30 years old then. Harako-san was a dominant personality, and Nishida-san was influenced by him. Talking over drinks was one habit instilled in us by Harako-san. At first, Nishidasan did not seem to understand why we went out to drink almost every day, but the frequency with which he joined us gradually increased. In fact, Nishida-san seemed to be more concerned about food than sake. Anyway, he ate a lot. Harako-san also encouraged Nishida-san to play go under his instruction. Nishida-san also became an avid player of the game. I will mention this again later. Let me add that Harako-san had a position of research associate in the Laboratory of Physical Anthropology, Kyoto University, for about eight years beginning in August, 1970.

Nishida-san often took postgraduate and undergraduate students to go to Mt. Takago on the Boso peninsula, Chiba Prefecture, to observe a troop of Japanese macaques, which was not fed by people any more. I also sometimes accompanied them. I remember that Nishidasan changed when he was there: he was full of vitality and walked very fast in the mountains. After Nishida-san began to work in Department of Anthropology, the number of postgraduates who majored in ecological anthropology increased. For instance, Dr. Taizo Iwano and Dr. Mariko Hasegawa (Hiraiwa), who specialized in primate ecol- 